Sri Lanka J. Aquat. Sci. 8 (2003): 67-83

\title{
Species Composition and Altitudinal Distribution of Fish in Upper Walawe River Basin in Sri Lanka
}

\author{
J. JINADASA*, H.M,B.K. HERATH AND J.M.H.S.K. \\ SAMARASINGHE \\ Department of Zoology, University of Sri Jayewardenepura \\ Nugegoda, Sri Lanka.
}

Corresponding author (E-mail: jins@sjp.ac.lk.)

\section{Abstract}

The fish assemblage and limnological factors at 154 sites of upper Walawe river basin, Sri Lanka were studied from April 1999 to March 2001. Out of the 26 species of fish recorded, 24 were indigenous and two were exotic. Of the indigenous species, six were endemic. Indigenous fish species were not present at an elevation above $1500 \mathrm{~m}$ MSL. The exotic species, Onchorynchus mykiss inhabits tributaries of Belihul Oya only in the Horton Plains at an elevation of $1900 \mathrm{~m}$ MSL. Garra ceylonensis is the most widely distributed endemic fish species. It was present at an elevation of even $1500 \mathrm{~m}$ MSL. Since there are no geomorphic impassable barriers, the altitudinal distribution of these fishes may be dependant on water temperature.

\section{Introduction}

The longitudinal distribution of fish in streams is characterized by massive difference in abundance both within and among species (Shelford 1911). The variation in altitudinal distribution of stream fish is an outcome of a complex relationship of channel physiography, environmental conditions and historic availability of water for fish (Vincent and Miller 1968). Since these parameters tend to vary with altitude, it is difficult to determine the precise influence of each of them on the distribution of stream fish. However, the work carried out on longitudinal succession of fish in the streams in USA revealed that the stream gradient and temperature were the major factors, which govern the fish distribution in different attitudinal levels. (Burton and Odum 1945; Trautman 1942; Kuehne 1962; Turner 1967). In Europe, different zones in strearns have been identified and each zone has been found to be characterized by a typical fish assemblage (Pires et al. 1962). However, since the faunal zonation is ambiguous in many streams in North America, the fish with respect to their altitudinal distribution are categorized as plain species, 
foothill species and mountain stream species (Ellis 1914). Silas (1952) was the first worker who described the speciation of fish and their habitat categories in Sri Lanka. Senanayake (1980) identified three icthyological zones in Sri Lanka, namely the Southwestern, Mahaweli and Dry zone, and described distinct faunal characteristics corresponding to each of these zones. Later, Pethiyagoda (1991) described qualitative altitudinal distribution of fish in Kalu, Kelani, Nilwala, Gin and Mahaweli river basins. However, he has left out a major river basin, namely the Walawe, which has the sixth largest catchment $\left(2442 \mathrm{~km}^{2}\right)$ in the island in his quantitative approach to relate the species diversity with elevation.

This paper describes the composition and diversity of fish in the upper Walawe river basin in relation to altitudinal changes.

\section{Material and methods}

This study was conducted in the upper Walawe river basin $\left(6^{\circ} 33^{\prime}\right.$ $6^{\circ} 50^{\prime} \mathrm{N}$ and $80^{\circ} 32^{\prime}-81^{\circ} \mathrm{E}$ ) at an altitude of over $200 \mathrm{~m}$ above MSL. Fish samples were collected from 48 major streams and 131 rivulets in the Upper Walawe river basin (Fig. 1), from April 1999 to March 2001 using gill nets (mesh size: $1.0-3.0 \mathrm{~cm}$ ), cast nets (mesh size: $2.0-3.0 \mathrm{~cm}$ ), drag-nets (mesh size: $0.5-1.0 \mathrm{~cm}$ ), and coop nets (mesh size: $0.1-0.25 \mathrm{~cm}$ ). The drag net was the mostly used gear in lower shallow reaches of the streams (up to a depth of $1 \mathrm{~m}$ ) and cast nets were used in deeper and wider areas and deep pools. In sinall brooks, scoop net was used to collect bottom dwelling fish as well as larvae and fry.

Fish collections were made after blocking an approximately $25 \mathrm{~m}$ long stretch of the stream including the riffles and pools using nets (Mahon and Baton 1980). The fish were collected from these blocked areas using above gear. The collected fish were identified using in the field guides (Mendis and Fernando 1962; Pethiyagoda 1991) and their standard lengths were measured.

The number of individuals of each species was counted and pooled according to the altitude. Species present in any one location were ranked according to their numerical abundance (the most abundant species-Rank 1; the second most abundance species- Rank 2, etc.) and the rank abundance curve for different altitudes were plotted as described by Manuel (1990). Diversity of fish fauna was determined using the Shannon-Weiner index (Shannon and Weiner 1949). Simpson's dominance index was used to assess the species dominance. Species richness was determined as the number of species present in that location. Further, the similarity of fish fauna among different altitudinal levels in terms of faunal affinity was determined using SØrenson index (SØrenson 1948). 
Fish species in upper Walawe river basin in Sri Lanka

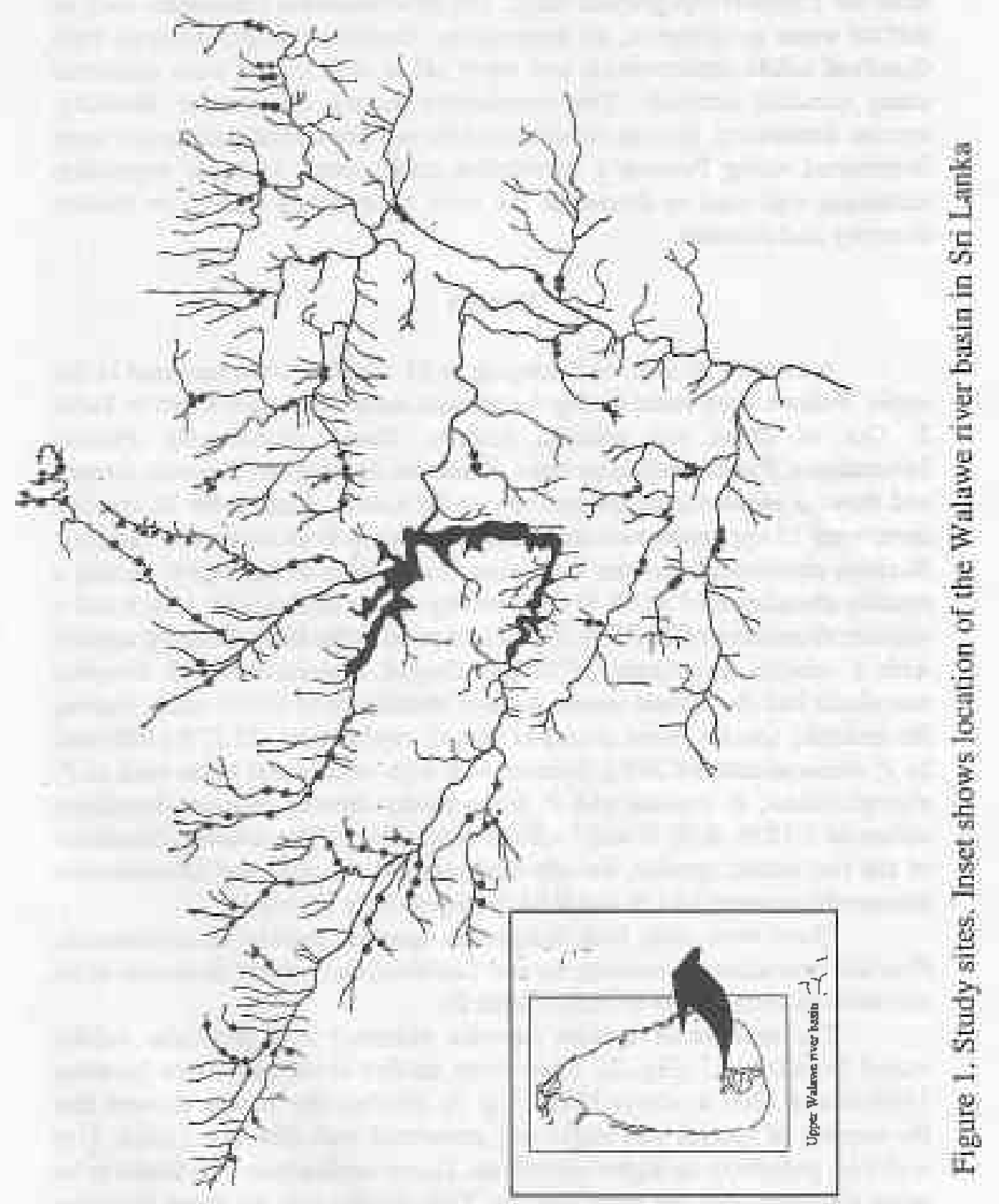




\section{J. Jinadasa et al.}

Elevation of each sampling site was determined using altimeter or from the 1:50,000 topographic maps. The environmental parameters such as surface water temperature, air temperature, dissolved oxygen content, total dissolved solids concentration and water $\mathrm{pH}$ at each station were measured using standard methods. The correlations among the species diversity, species dominance, species richness and the environmental parameters were determined using Pearson's correlation coefficients. Multiple regression technique was used to determine the most contributing factors on species diversity and richness.

\section{Results}

A total of 26 species belonging to 11 families were recorded in the upper Walawe river basin during the present study. These are listed in Table 1. Out of them, six species, namely, Garra ceylonensis, Puntius bimaculatus, Puntius nigrofasciatus, Schistura notostigma, Belontia signata and Puntius pleurotaenia are endemic to Sri Lanka. Among the 26 species, there were 15 cyprinids, two cichlids and one each from other nine families. Rasbora daniconius was the most abundarit species in the region having a relative abundance of $32.08 \%$ followed by Garra ceylonensis, which had a relative abundance of $21.27 \%$. P. pleurotaenia is the least abundant species with a relative abundance of $0.02 \%$ Ompok bimaculatus and Etroplus maculatus had the second lowest relative abundance of $0.03 \%$ each. Among the endemic species, most abundant was G. ceylonensis $(21.27 \%$ ) followed by $P$. bimaculatus (14.26\%). Species with high ornamental value such as $P$. nigrofasciatus, $B$. signata and $P$. bimaculatus showed relative abundance values of $5.12 \%, 0.78 \%$ and $14.26 \%$ respectively. The relative abundance of the two exotic species, namely Onhcorynchus mykiss and Oreochromis mossambicus were $0.43 \%$ and $0.04 \%$ respectively (Table 1 ).

There were only four indigenous species, namely $G$. ceylonensis, Poecilia reticulata, S. notostigma and Lepidocephalychthys thermalis at an elevation of above $1000 \mathrm{~m}$ MSL (Table 2).

The number of species (species richness) in a particular habitat varied from 0 to 17 (Fig. 2). There were no fish at the elevations between $1400 \mathrm{~m}$ and $1900 \mathrm{~m}$ above MSL (Fig. 3). Further, the results showed that the number of species was negatively correlated with elevation (Table 3) ( $r$ $=-0.914, \mathrm{p}<0.005$ ). In higher elevations, Garra ceylonensis was found to be more abundant than the other species. This species was the most abundant fish species at altitudes of above $600 \mathrm{~m}$ MSL (Table 2).

Shannon -Weiner index was negatively correlated $(r=-0.95$, p<0.005) with elevation (Table 3). The rank abundance curves (Fig. 4) for different elevations further showed that fish communities at $700 \mathrm{~m}, 800 \mathrm{~m}$, $1000 \mathrm{~m}$ and $1100 \mathrm{~m}$ above MSL elevations had one dominating 
Fish species in upper Walawe river basin in Sri Lanka

Table 1. Species composition of fish in Upper Walawe river basin.

\begin{tabular}{|c|c|c|}
\hline Family & Species & $\begin{array}{c}\text { Relative } \\
\text { abundance } \\
(\%)\end{array}$ \\
\hline \multirow[t]{7}{*}{ Cyprinidae } & Amblypharyngodon melettinus(Valenciennes, 1844) & 2,10 \\
\hline & Chela laubuca (Hamilton,1822) & 212 \\
\hline & Danio malabaricus (Jerdon, 1849) & 0.06 \\
\hline & Esomus thermoicos (Valenciennes,1842) & 0.47 \\
\hline & Garra ceylonencis (Bleeker,1863) \# & 21.27 \\
\hline & Puntius amphibius (Valenciennes 1843) & 0.05 \\
\hline & Puntius bimaculalus (Bleeker, 1863) \# & 14.26 \\
\hline 20 & Puntius chola (hamilton, 1822) & 397 \\
\hline \multirow{3}{*}{ 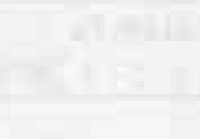 } & Puntius dorsalis (Jerdon, 1849) & 0.10 \\
\hline & Puntius filamentosus (Valenciemmes, 1844) & 0.55 \\
\hline & Puntius nigrofasciatus (Gunther, 1868 ) \# & 5.12 \\
\hline \multirow{4}{*}{ 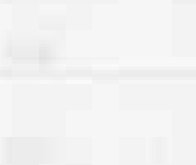 } & Puntius pleurotaenia (Bleeker, 1863) \# & 0.02 \\
\hline & Puntius sarana (Hamitton,1822) & 009 \\
\hline & Rasbora daniconius (Hamilton, 1822) & 32,08 \\
\hline & Tor khurdee (Sykes,1841) & 225 \\
\hline Balitoridae & Schistura nolostigma (Bleeker, 1863) \# & 5.16 \\
\hline Cobitidae & Lepidocephalichthys themalis (Valenciennes,1846) & 2.59 \\
\hline Bagridae & Mystus keletius (Bloch 1794) & 0.40 \\
\hline Siluridae & Ompok bimaculatus (Bloch, 1794) & 0.03 \\
\hline \multirow[t]{2}{*}{ Cichlidae } & Etroplus maculatus (Bloch, 1785) & 0.03 \\
\hline & Oreochromis mossambicus (Peters, 1859) & 0.04 \\
\hline Anabantidae & Anabas testudineus (Bloch, 1795) & 0.10 \\
\hline Belontidae & Belontia signata (Gunther, 1861) \# & 0.78 \\
\hline Channidae & Channa gachua (Bleeker, 1877) & 1.07 \\
\hline Poeciliidae & Poecilia reficulata (Peters, 1859 ) & 4.84 \\
\hline Salmonidae & Onchorynchus mykiss (Walbaum 1792) & 0.43 \\
\hline
\end{tabular}

\# endemic species

species. This species was Garra ceylonensis (Table 3). From the altitudes $200 \mathrm{~m}$ to $500 \mathrm{~m}$ three species were dominating fish communities (Figs 4a and $b$ ). At these altitudes, $R$. daniconius was the dominant species followed by $P$. bimaculatus and the third species changed according to the altitude (Table 2). At the altitude of $500 \mathrm{~m}$ above MSL, 17 species were recorded with only one dominating species, $R$. daniconius (Table 2). In comparison to other elevations, in this region fish species were evenly distributed. In the fish community at $600 \mathrm{~m}$ elevation, $P$. bimaculatus was the dominating species. 


\section{J. Jinadasa et al.}

Table 2. Numerical rank abundance of species found at each elevation (Altitudes $1500 \mathrm{~m}, 1600 \mathrm{~m}, 1700 \mathrm{~m}$ and $1800 \mathrm{~m}$ above MSL were omitted from the analysis as no fish were found).

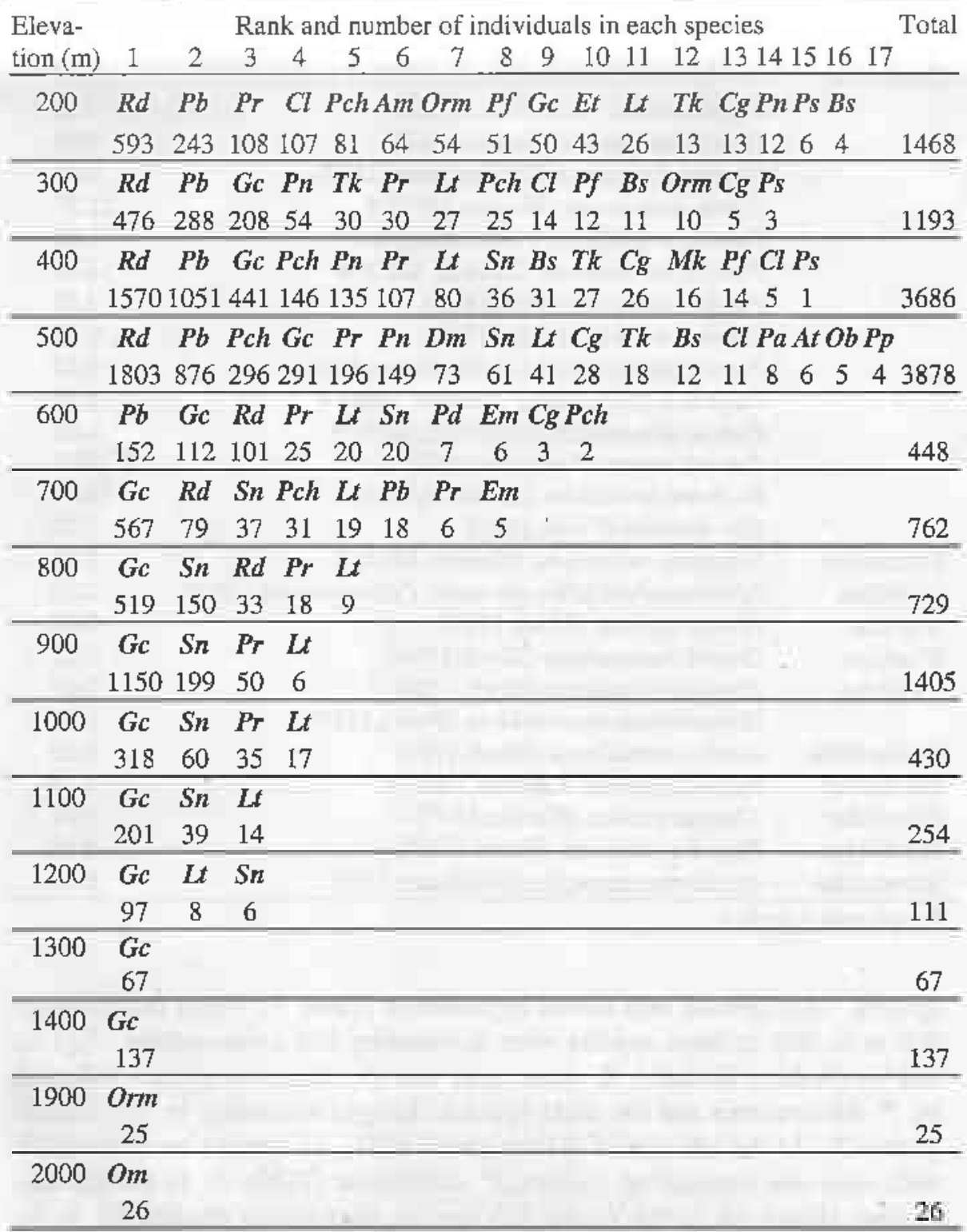

Am-A, melettinus, Cl-C. laubuca, Dm- $D$ malabaricus, Gc-G. ceylonensis, Pb-P. bimaculatus, Pch- $P$, chola, Pd-P. dorsalis, Pf-P. filamentosus, Pn-P, nigrofasciatus, Pa-P amphibius, Rd-R daniconius, Tk-T. khurdee, Ps-P. saranta, Et-E thermoicos, Pp-P. pleurotaenia, Sn-S. notostigma, Lt-L thenmalis, Mk-M. kelatius, Ob-O. bimaculatus, Em-E. maculatus, Orm- $O$, mossambicus, At-A testudineus, Bs- $B$ signata, $\mathrm{Cg}-C$. gachua, $\mathrm{Pr}-P$. reticulata, Om- $O$ mykiss 
Fish species in upper Walawe river basin in Sri Lanka

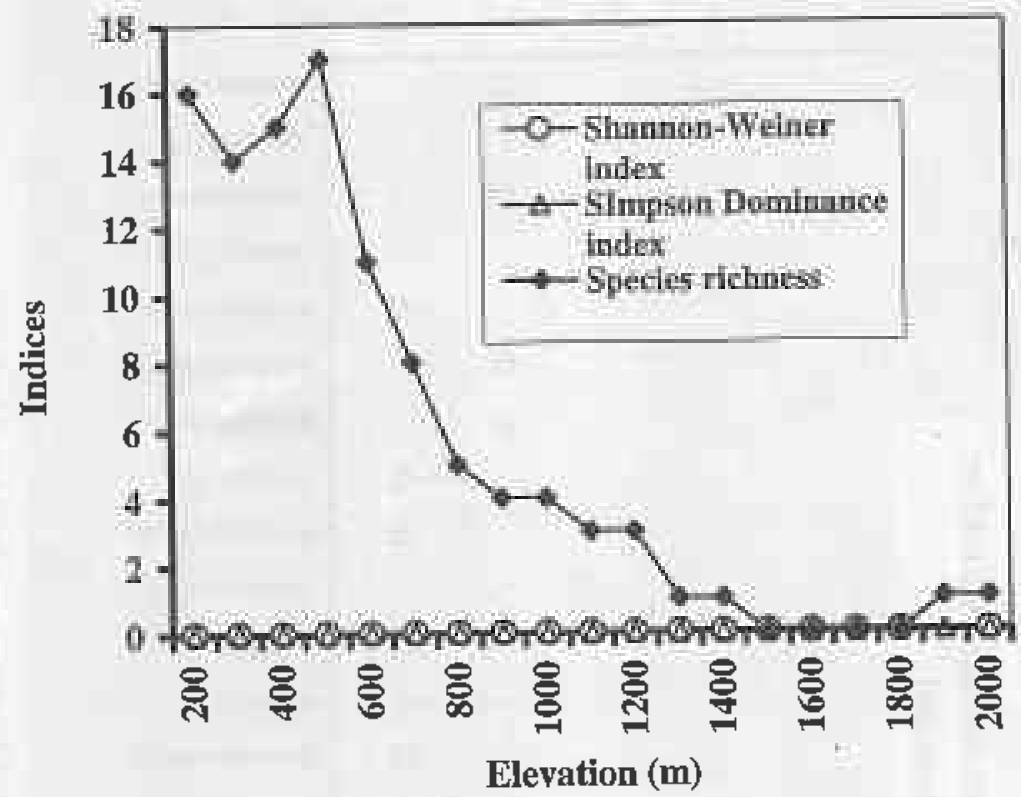

Figure 2. Variation of diversity indices and species richness with elevation.

The Pearson's correlation matrix (Table 3 ) indicates that the dissolved axygen concentration of the water has a signifieant positive relationship with elevation. The upper region of the basin bears mone rapids and falls and the aeration results in high dissolved oxygen concentrations in these regions. Water $\mathrm{pH}$ had the most significant downstream trend of changing from slightly ucidic to neutral or slightly alkuline ( $\mathrm{Fig}, 5)(\mathrm{r}=-0.847, \mathrm{p}=$ $0.00)$. Total Dissolved Solid (TDS) concentration significantly increased downstream. Water (emperature $(\mathrm{r}=0,886, \mathrm{p}=0,00)$ too showed the similar pattern as exhibited by TDS.

The highest values for $\$ \emptyset$ renson index were recorded for adjacent elevational ranges (Table 4). The greater the altitudinal difference, lesser the values for $S \emptyset$ renson index. However, the lowest value of 11 was recorded between $500 \mathrm{~m} \& 1300 \mathrm{~m}$ elevations also between $500 \mathrm{~m}$ and $1400 \mathrm{~m}$ elevations. The highest value of 100 was recorded for $900 \mathrm{~m}-1000 \mathrm{~m}$, $1100 \mathrm{~m}-1200 \mathrm{~m}$ and $1300 \mathrm{~m}-1400 \mathrm{~m}$ above MSL (Table 4).

The resalts of the multiple regression unalysis of Shannon Weiner index with environmental parameters (Table 5) revealed that only the dissolved oxygen content $(\mathrm{p}=0.05)$, elevation $(\mathrm{p}=0.01)$ and water temperature $(p=0.00)$ had a sugnificant effect on determining the species 
J. Jinadasa et al

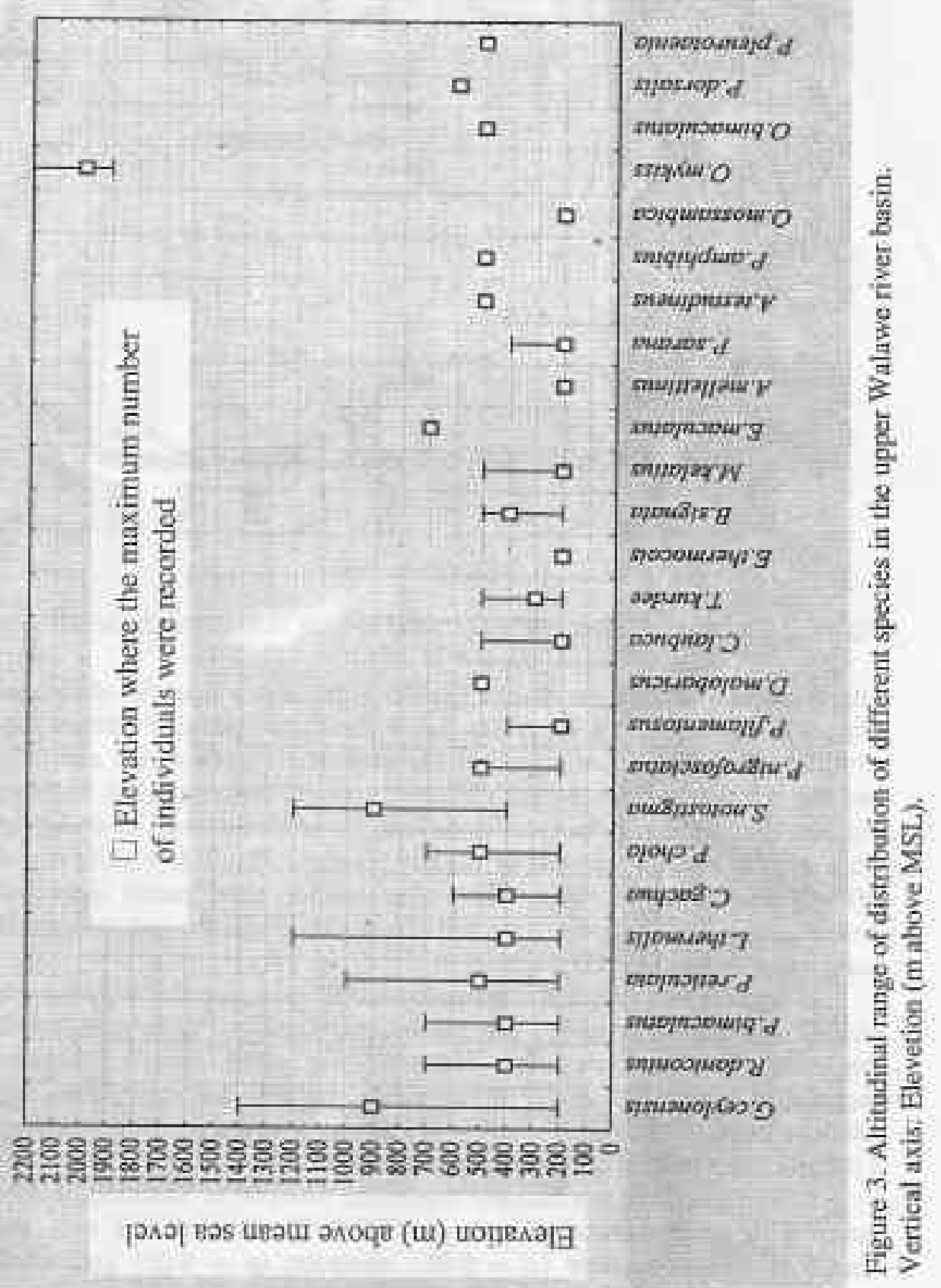


Fish species in upper Walawe river basin in Sri Lanka

Table 3. Pearson's correlation coefficients among different environmental parameters, number of species, Shannon Weiner Indices and Simpson dominance indices (Values indicated by ${ }^{*}$ are significant at $5 \%$ level.).

$\begin{array}{llll}\text { Elevation } & \mathrm{PH} & \mathrm{DO} & \text { TDS }\end{array}$

\begin{tabular}{|c|c|c|c|c|c|}
\hline Elevation & . & 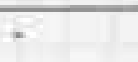 & 8 & - & G \\
\hline Water $\mathrm{pH}$ & $-0.847 *$ & - & - & $=$ & - \\
\hline Dissolved Oxygen & $0.826^{*}$ & $-0.877^{*}$ & - & - & $\Rightarrow$ \\
\hline $\begin{array}{l}\text { concentration } \\
\text { (DO) }\end{array}$ & & & & & \\
\hline $\begin{array}{l}\text { Total Dissolved } \\
\text { solids (TDS) }\end{array}$ & $-0.830^{*}$ & $0.883^{*}$ & $-0.915^{*}$ & - & - \\
\hline $\begin{array}{l}\text { Surface water } \\
\text { temperature (T) }\end{array}$ & $-0.886^{*}$ & $0.812^{*}$ & $-0.822 *$ & $0.932 *$ & - \\
\hline Species richness & $-0.914^{*}$ & $0.854 *$ & $-0.826^{*}$ & $0.904^{*}$ & $0.952 *$ \\
\hline $\begin{array}{l}\text { Shannon Weiner } \\
\text { index }\end{array}$ & $-0.950^{*}$ & $0.842^{*}$ & $-0.865^{*}$ & $0.905^{*}$ & $0.969 *$ \\
\hline $\begin{array}{l}\text { Simpson } \\
\text { dominance index }\end{array}$ & 0.098 & -0.245 & 0.202 & -0.318 & -0.308 \\
\hline
\end{tabular}

diversity in any particular study site. When the above analysis was done for the number of species at each elevation (Table 6), none of the environmental parameter appeared to have a significant effect on determining the number of species at any given location.

\section{Discussion}

A total of 24 indigenous and two exotic fish species were recorded during the present survey carried out in the streams of upper Walawe river basin at the elevations more than $200 \mathrm{~m}$ above MSL. Pethiyagoda (1991) considered only five river basins in preparing the distribution tables for the freshwater fishes in Sri Lanka. These were the Kelani, Kalu, Gin, Nilwala and Mahaweli river basins. He has not listed the species that are found in the Walawe river basin. Later Herath and Jinadasa (2000) listed 20 species in some selected streams of the Walawe river basin. Eventually, when considering all data available, it appears that at a particular elevation, the upper Walawe river basin supports the most number of species among all the river systems in Sri Lanka. During the present survey, Chela laubuca was found in the elevational range of $400-500 \mathrm{~m}$ above MSL. However, 


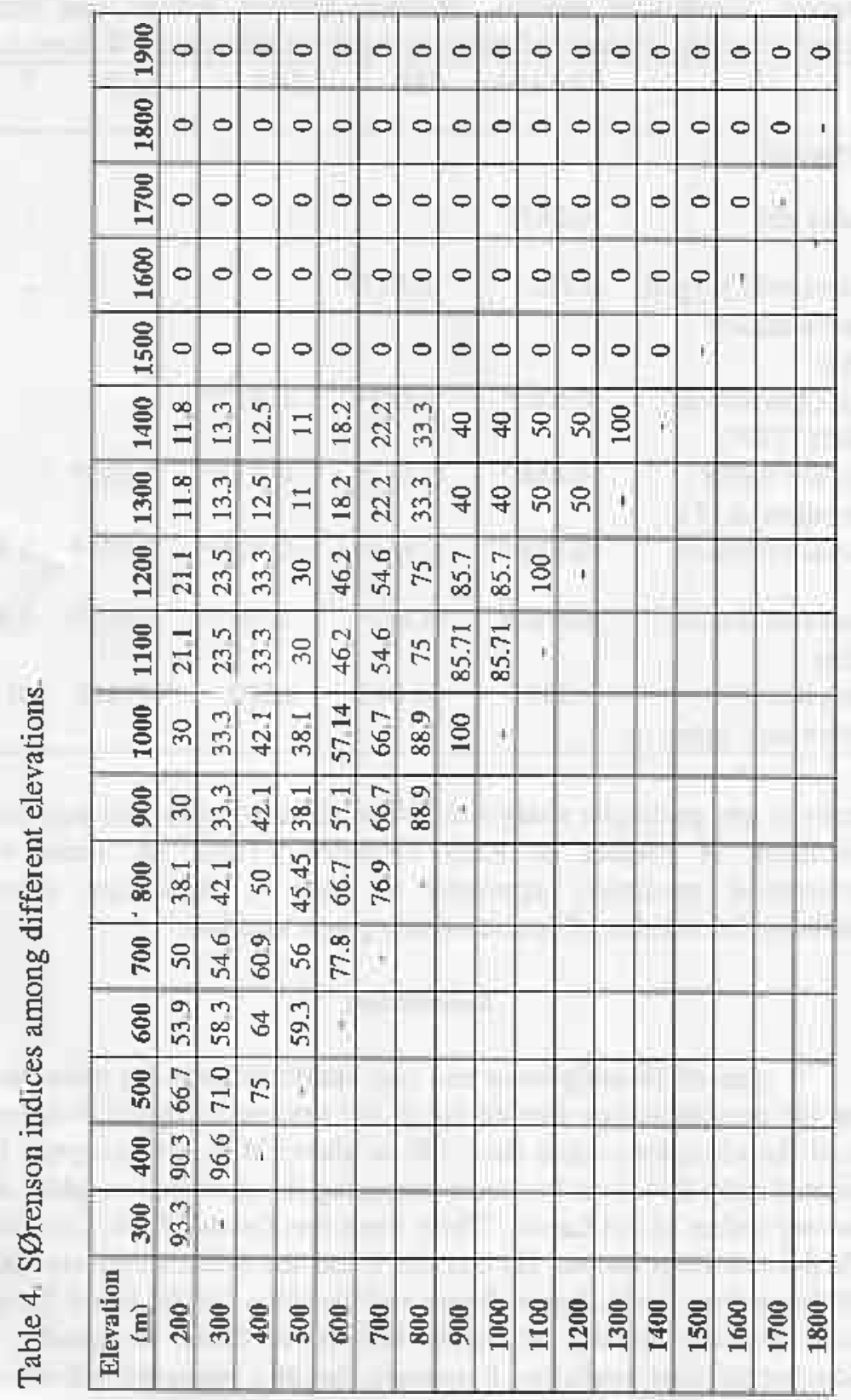


J. Jinadasa et al.
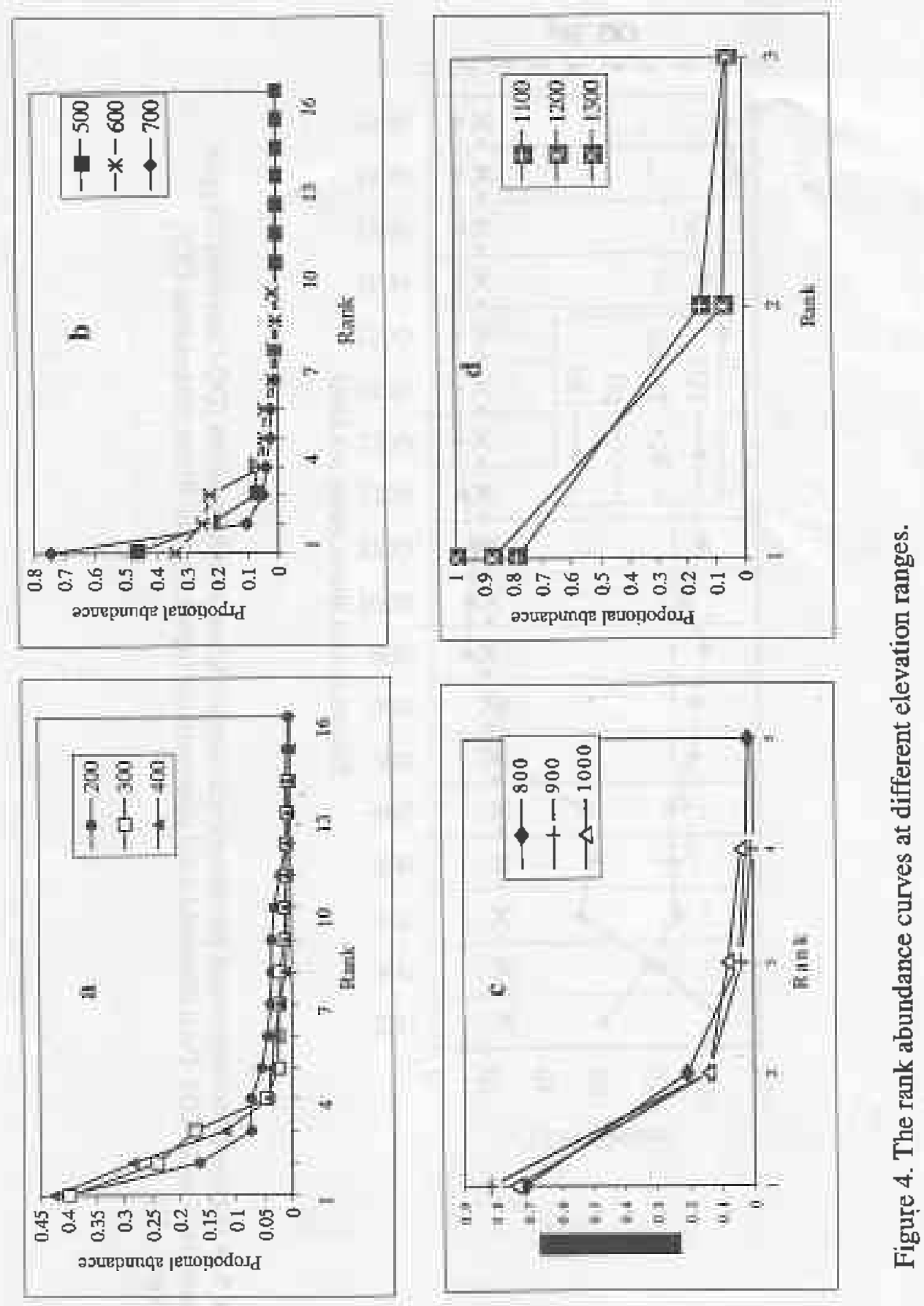


\section{J. Jinadasa et al.}
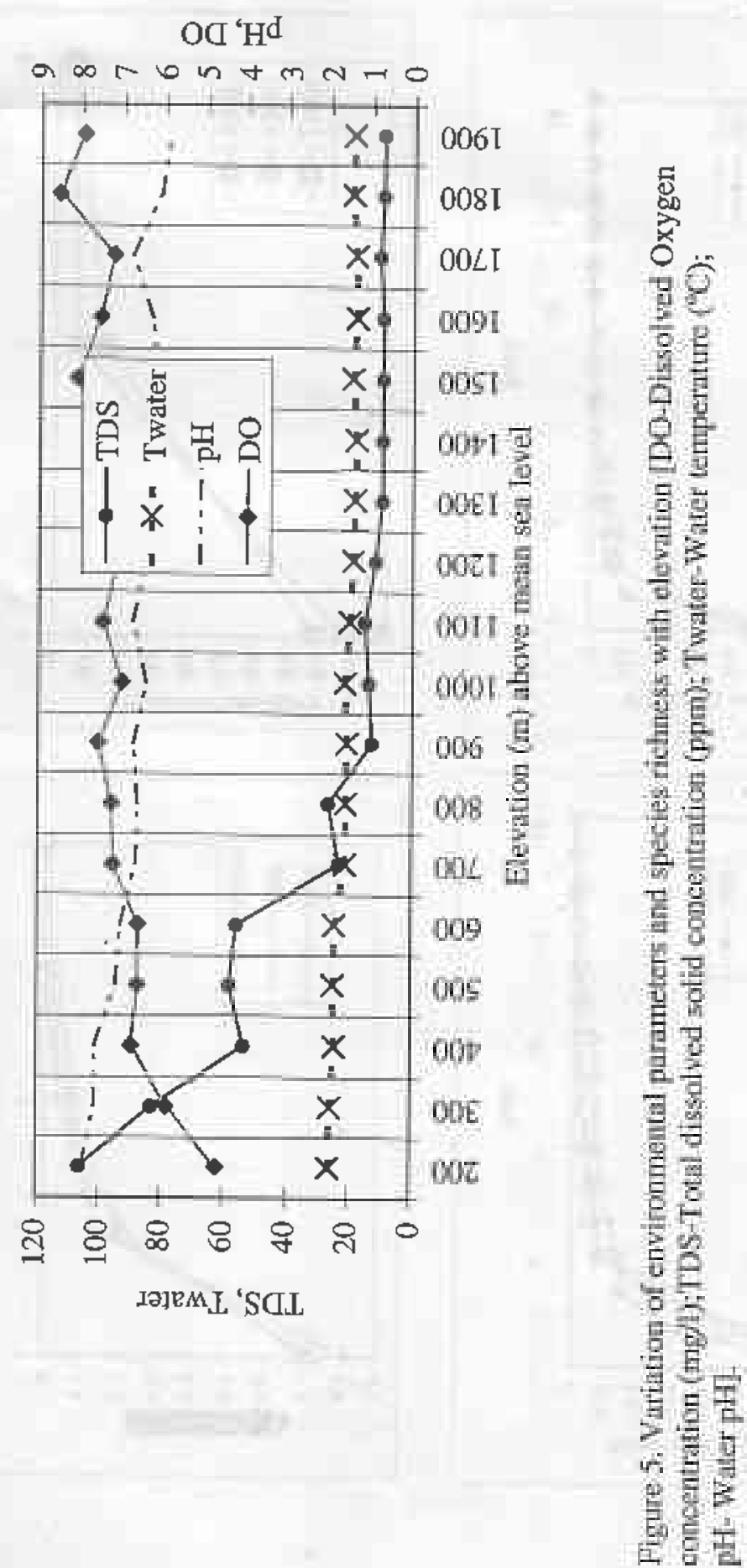
Fish species in upper Walawe river basin in Sri Lanka

Table 5. The results of multiple regression analysis between ShannonWeiner Index (SHI) and environmental parameters. DO = Dissolved oxygen content; TDS $=$ Total dissolved solids content; $T_{\text {waler }}=$ Water temperature The regression equation:

SHI $=-1.59-0.000692$ Elevation $-0.035 \mathrm{pH}-0328 \mathrm{DO}-0.0119$ TDS + $0.325 \mathrm{~T}_{\mathrm{w}+\mathrm{m}}$

\begin{tabular}{lllll}
\hline Predictor & coefficient & $\begin{array}{l}\text { Standard } \\
\text { deviation }\end{array}$ & $\mathrm{t}$ & $\mathrm{p}$ \\
\hline Constant & -1.5930 & 2.1690 & -0.73 & 0.478 \\
Elevation & -0.0006 & 0.0002 & -3.20 & 0.009 \\
$\mathrm{PH}$ & -0.0345 & 0.1885 & -0.18 & 0.858 \\
$\mathrm{DO}$ & -0.3284 & 0.1491 & -2.20 & 0.050 \\
TDS & -0.0119 & 0.0077 & -1.55 & 0.151 \\
$\mathrm{~T}_{\text {waler }}$ & 0.3245 & 0.0788 & 4.12 & 0.002 \\
\hline
\end{tabular}

\begin{tabular}{lllccc}
\hline \multicolumn{2}{l}{ Analysis of variance } & & & & \\
\hline Source & DF & SS & MS & F & p \\
\hline Regression & 6 & 18.7744 & 3.1291 & 119.52 & 0.000 \\
Residual Error & 11 & 0.2880 & 0.0262 & & \\
Total & 17 & 19.0624 & & & \\
\hline
\end{tabular}

$\mathrm{S}=0.1618 ; \mathrm{R}^{2}=0.985$

Chela laubuca has not been recorded in such a high elevation perhaps because of lack of detailed studies. Lepidocephalichthys thermalis has been recorded by Pethiyagoda (1991) and Mendis and Fernando (1962) at elevations up to $600 \mathrm{~m}$ and $500 \mathrm{~m}$ respectively. However, during the present survey, this species was found to inhabit up to an elevation of $1200 \mathrm{~m}$ above msl.

Earlier studies have shown that $S$. notostigma, $P$. bimaculatus and G. ceylonensis are confined to an eleyation below $1000 \mathrm{~m}$ (Mendis and Fernando 1962; Pethiyagoda 1991). However, during the present survey, $S$. notostigma was found to be distributed up to an elevation of $1400 \mathrm{~m}$ while $P$. bimatulatus and $G$. ceylonensis was found to be distributed up to an elevation of $1100 \mathrm{~m}$ and $1500 \mathrm{~m}$ respectively. Although, Pethiyugoda (1991) has reported that $A$. testudineus, $B$. signata and Etroplus maculatus are distributed in the elevations above $1000 \mathrm{~m}$, results of this survey indicated that in the upper Walave river basin, these species are present in elevations below $1000 \mathrm{~m}$. $P$. pleurotaenia, the endemic cyprinid was recorded only in one stream in the upper Walawe river basin. This species has been recorded only in Nilwala and Kelani river basins by Pethiyagoda (1991). 


\section{J. Jinadasa et al.}

Table 6. The results of multiple regression analysis between number of species (No.Sp) and environmental parameters. DO - Dissolved oxygen content; TDS - Total dissolved solids content; $\mathrm{T}_{\text {watr }}$ - Water temperature. The regression equation:

No.Sp $=-32.6-0.00345$ Elevation $+1.82 \mathrm{pH}-0.12 \mathrm{DO}-0.0273$ TDS + $1.83 \mathrm{~T}_{\text {water }}$

\begin{tabular}{lccrll}
\hline \multicolumn{1}{c}{ Predictor } & Coefficient & $\begin{array}{c}\text { Standard } \\
\text { deviation }\end{array}$ & T & P & \\
\hline Constant & -32.640 & 25.1 & -1.30 & 0.220 & \\
Elevation & -0.003 & 0.002 & -1.38 & 0.196 & \\
PH & 1.820 & 2.182 & 0.83 & 0.422 & \\
$\mathrm{DO}$ & -0.123 & 1.725 & -0.07 & 0.945 & \\
$\mathrm{TDS}$ & -0.027 & 0.089 & -0.31 & 0.765 & \\
$\mathrm{~T}_{\text {waler }}$ & 1.825 & 0.911 & 2.00 & 0.070 & \\
& & & & & \\
\hline Analysis of variance & & & & \\
\hline Source & $\mathrm{DF}$ & $\mathrm{SS}$ & $\mathrm{MS}$ & $\overline{\mathrm{F}}$ & $\mathrm{p}$ \\
\hline Regression & 6 & 591.41 & 98.56 & 28.10 & 0.000 \\
Residual Error & 11 & 38.58 & 3.508 & & \\
Total & 17 & 630.00 & & & \\
\hline
\end{tabular}

$\mathrm{S}=1.873 ; \mathrm{R}^{2}=0.939$

In the upper Walawe river basin, $R$. daniconius, $P$. bimaculatus and $G$. ceylonensis had relatively wide distributions. These three species have also been listed as widely distributed species in Sri Lanka (Senanayaka and Moyle 1982, Pethiyagoda 1991). Species whose distribution was restricted to one location were $O$. mykiss, $P$. pleurotaenia, $O$. bimaculatus, $P$, dorsalis, P. amphibius, E. maculatus and A. testudineus.

The Pearson's correlation analysis showed that fish diversity and species richness in the upper Walawe river basin are correlated with allitude, water $\mathrm{pH}$, dissolved oxygen concentration, total dissolved solids and water temperature and multiple regression analysis further revealed that dissolved oxygen and water temperature are the factors, contributing most for species diversity. These two parameters were listed as governing factors of fish distribution in Oregon, DSA (Ruthert et al. 1999) and in northem Hokkaido, Japan (Mikio and Nakuno 2001)

Although results of multiple regression analysis between environmental parameters and Shannon-Weiner index indicated that the elevation, dissolved oxygen and water temperature contributed most to the 
Fish species in upper Walawe river basin in Sri Lanka

fish diversity (Table 5), since the constant value for elevation is too small $(-0.0006)$, effect from the elevation factor is negligible. The results of the multiple regression analysis between species richness and environmental factors did not reveal any significant relationship ( $p>0.05$ ) at $95 \%$ confidence level) contributing to the species richness in the area. However, water temperature can be considered as the factor contributing most $(\mathrm{p}=$ 0.07 ), out of the measured parameters ( $p=0.07$ ). Therefore, the results of the present study indicate that the dissolved oxygen content and water temperature are the environmental factors that contribute most to the diversity of fishes in the upper Walawe river basin.

\section{Conclusion}

This study revealed that the number of species increased from the headwaters to downstream. This trend had been documented for streams in temperate regions (Pires et al. 1999). In addition, the environmental parameters such as water $\mathrm{pH}$, total dissolved solids and surface water temperature increased and the dissolved oxygen content decreased in a downstream direction. In high altitudes of over $1000 \mathrm{~m}$ only three indigenous species, namely $G$. ceylonensis, $L$ thermalis, and $S$. notostigma were present. G. ceylonensis was the only endernic species found in the highest elevations. No indigenous fish species were found at an elevation of more than $1500 \mathrm{~m}$ above MSL.

\section{Acknowledgement}

Financial assistance provided by National Science Foundation under the research grants No. ZSSL/99/01 is highly appreciated.

\section{References}

Burton, G.W. \& E.P. Odum 1945.

The distribution of stream fishes in the vicinity of Mountain Lake. Virgin in Ecology 26(2): 182-194.

Eills, M.M. 1914.

Fishes of Colorado. The University of Colorado Studies 11(1): 5136.

Herath,. H.M.B.K. \& J. Jinadasa 2000.

Species diversity, population density and distribution of fish in selected streams of Walawe river basin. Proceedings of the sixth Annual Scientific Sessions of the Sri Lanka Association for Fisheries and Aquatic Resources. p. 74 . 
Keuhne, R.A. 1962.

A classification of streams illustrated by distribution in an eastern Kentacky creek. Ecology 43: 608-614.

Mahon, R \& E.K. Balon 1980.

Quantitative collection of fishes from small fast-flowing streams.

Archives für Hydrobiology 90: 324-329.

Manuel Jr., C.M. 1990.

Ecology-Concepts and Applications, McGraw Hill, New Jersey.

Mendis,A.S \& C.H. Fernando 1962.

A guide to the freshwater fauna of Ceylon. Bulletin of the Fisheries Research Station, Ceylon 12: 101-125.

Mikio Inoue \& Shigeru Nakano 2001.

Fish abundance and habitat relationships in forest and grassland streams, northern Hokkaido, Japan. Ecological Research 16: 233247.

Pires, A.M., I.G. Cowx \& M.M. Coelho 1999.

Seasonal changes in the fish community structure of intermittent streams in the middle reaches of the Guadiana basin, Portugal. Journal of Fish Biology 54: 234-249.

Pethiyagoda, R. 1991.

Freshwater fishes of Sri Lanka. Wildlife Heritage Trust, Colombo. 362p.

Rathert, D., D. White, ' C. Sifneos \& R.M. Hughes 1999.

Environmental correlates of species richness for native freshwater

fish in Oregon, USA. Joumal of Biogeography 26: 156-273.

Senanayake, F.R. 1980.

The Biogeography and Ecology of the Inland Fishes of Sri Lanka.

Ph.D. thesis. Department of Wildlife and Fisheries Biology, University of Califonia, Davis.

Senanayake, FR \& P.B.Moyle 1982.

Conservation of freshwater fishes of Sri Lanka. Biological

Conservation 22:181-195.

Shannon, C.E. \& W. Weiner 1949.

The Mathematical Theory of Communication. University of Illinois Press. $117 \mathrm{P}$.

Shelford, V.E. 1911.

Ecological succession 1: Stream fishes and the method of physiographic analysis. Biological Bulletin 21: 9-34.

Silas, E.G. 1952.

Speciation among the freshwater fishes of Ceylon, Bulletin of National Institute of Science, India 7: 248-259. 
Fish species in upper Walawe river basin in Sri Lańka

SØrenson, F. 1948.

A method of establishing group of equal amplitude in plant sociology based on similarity of species content and its application to analysis of the vegetation of Danish commons. Biol. Skr. 5: 1154.

Trautman, M.B. 1942.

Fish distribution and abundance correlated with stream gradient as a consideration in stocking programs. Transactions of the $7^{\text {th }}$ American Wildlife Conference, 211-223.

Turner,W.R. 1967.

A pre- and post- impoundment survey of Middle Fork of the Kentucky River. Kentucky Fisheries Bulletin No.51, 72p.

Vincent, R.E \& W.H. Miller 1911.

Altitudinal distribution of brown trout and other fishes in a headwater tributary of the south Platte River, Colorado. Ecology 50 (3): $465-467$. 